\title{
Effectiveness of topically applied chamomile in the treatment of oral mucositis: a
}

\section{literature review}

\section{Eficácia da camomila aplicada topicamente no tratamento da mucosite oral: uma revisão da}

\section{literatura}

Efectividad de la manzanilla aplicada tópicamente en el tratamiento de la mucositis oral: revisión de la literatura

\begin{abstract}
Oral mucositis $(\mathrm{OM})$ is one of the main adverse events observed during the treatment of neoplasms, especially in relation to head and neck $(\mathrm{H} \& \mathrm{~N})$ cancer. Complications, initially non-infectious of OM, can significantly compromise the chosen therapy, extend the hospitalization period and decrease the quality of life of patients with H\&N cancer. Therefore, the present work presents a narrative review that gathers, presents and discusses studies on the relationship between the topical application of chamomile-based pharmaceutical products and the treatment of oral mucositis, with an emphasis on its effectiveness. A literature search was conducted in August 2021 using PubMed, Scielo and LILACS. From literature search was identified 869 papers, of which 06 were selected to answer the guiding question of this study. Finally, it could be seen that chamomile has great potential to help manage OM, as well as other oral complications, especially in cases of patients undergoing $\mathrm{H} \& \mathrm{~N}$ cancer treatments using radiotherapy. Furthermore, formulations containing chamomile have been shown to be effective in slowing the progression of OM grades. However, it is necessary to evaluate in each formulation, the possible impacts of each pharmaceutical adjuvant, as well as the adverse events capable of increasing pharmacotherapeutic adherence.
\end{abstract}

Keywords: Cancer; Mucositis; Therapeutic potential; Medicinal plant.

\section{Resumo}

A mucosite oral (MO) é um dos principais eventos adversos observados durante o tratamento das neoplasias, principalmente em relação ao câncer de cabeça e pescoço (CP). Complicações, inicialmente não infecciosas de MO, podem comprometer significativamente a terapia escolhida, prolongar o período de internação e diminuir a qualidade de vida dos pacientes com câncer de CP. Portanto, o presente trabalho apresenta uma revisão narrativa que reúne, apresenta e discute estudos sobre a relação entre a aplicação tópica de produtos farmacêuticos à base de camomila e o tratamento da mucosite oral, com ênfase na sua eficácia. Uma pesquisa bibliográfica foi realizada em agosto de 2021 usando PubMed, Scielo e LILACS. A partir da busca bibliográfica foram identificados 869 artigos, dos quais 06 foram selecionados para responder à questão norteadora deste estudo. Por fim, pôde-se constatar que a camomila tem grande potencial para auxiliar no manejo da MO, assim como outras complicações orais, principalmente nos casos de pacientes em tratamento do câncer de CP com radioterapia. Além disso, formulações contendo camomila têm se mostrado eficazes em retardar a progressão dos graus de MO. No entanto, é necessário avaliar em cada formulação, os possíveis impactos de cada adjuvante farmacêutico, bem como os eventos adversos capazes de aumentar a adesão farmacoterapêutica.

Palavras-chave: Câncer; Mucosite; Potencial terapêutico; Planta medicinal. 


\section{Resumen}

La mucositis oral (MO) es uno de los principales eventos adversos observados durante el tratamiento de las neoplasias, especialmente en relación con el cáncer de cabeza y cuello (CC). Las complicaciones, inicialmente no infecciosas de la MO, pueden comprometer significativamente la terapia elegida, prolongar la estancia hospitalaria y disminuir la calidad de vida de los pacientes con cáncer de CC. Por ello, el presente trabajo presenta una revisión narrativa que recoge, presenta y discute estudios sobre la relación entre la aplicación tópica de productos farmacéuticos a base de manzanilla y el tratamiento de la mucositis oral, con énfasis en su efectividad. Se realizó una búsqueda bibliográfica en agosto de 2021 utilizando PubMed, Scielo y LILACS. De la búsqueda bibliográfica se identificaron 869 artículos, de los cuales se seleccionaron 06 para dar respuesta a la pregunta orientadora de este estudio. Finalmente, se pudo ver que la manzanilla tiene un gran potencial para ayudar en el manejo de la MO, así como otras complicaciones orales, especialmente en los casos de pacientes en tratamiento por cáncer de CC con radioterapia. Además, se ha demostrado que las formulaciones que contienen manzanilla son eficaces para ralentizar la progresión de los grados de MO. Sin embargo, es necesario evaluar en cada formulación, los posibles impactos de cada adyuvante farmacéutico, así como los eventos adversos capaces de incrementar la adherencia farmacoterapéutica.

Palabras clave: Cáncer; Mucositis; Potencial terapéutico; Planta medicinal.

\section{Introduction}

Oral mucositis $(\mathrm{OM})$ is one of the main adverse events observed during the treatment of neoplasms, especially in relation to head and neck $(\mathrm{H} \& \mathrm{~N})$ cancer. It is an inflammatory response of the oropharyngeal mucosa, usually ulcerative and extremely painful, observed in patients undergoing both radiotherapy (RT) and chemotherapy (CT). The process of ulceration and infections of the oral mucosa occur as a result of the treatment of cancer located in regions close to the oral cavity, such as the lips, middle ear, oral and nasal cavities, pharynx and larynx (Hong et al., 2019; Daugèlaitè et al., 2019; Santos et al., 2011; Elad et al., 2020). The treatments in question are not specific and as such regions have high mitotic activity and high cell renewal rate, non-neoplastic cells are rapidly affected, both by radiation and by the cytotoxicity of the therapy. In this particular case, adverse events include OM, dermatitis, hyposalivation and xerostomia, rampant caries, pharyngitis, discomfort, osteoradionecrosis and trismus (Sari et al., 2014). Recent studies show that OM affects $20 \%$ to $40 \%$ of patients who receive conventional CT, over $80 \%$ of those who receive high doses of CT, $100 \%$ of patients with H\&N cancer who receive RT plus $75 \%$ to $100 \%$ of patients with hematopoietic stem cell transplantation (HSCT) (Santos et al., 2011; Sari et al., 2014; Elad et al., 2020).

According to the World Health Organization, OM can be classified into five grades, based on the clinical appearance and functional status of the patient, where for grade 0 , there are no signs or symptoms, grade 1 (low-moderate) the mucosa is erythematous and painful, in grade 2 (moderate) there are ulcers and the patient eats normally, in grade 3 (severe), the patient has ulcers and only feeds with liquids, and in grade 4 (extremely severe) urgent intervention is needed, as the patient cannot eat orally. This can lead to discontinuation, interruption or reduction of the defined dose for cancer treatment (Medeiros et al., 2013; Kawashita et al., 2020; Bensinger et al., 2008).

The pathogenesis of OM is complex, as factors related to the treatment and the patient are determinant in the severity of this event. These factors are reported by the description of clinical cases, reviews, descriptive studies and some analytical studies (Brown \& Gupta, 2020). Its treatment, in general, is only symptomatic and will depend on the degree of severity of the lesion. Among the strategies for managing $\mathrm{OM}$, the use of saline ( $\mathrm{NaCl} 0.9 \%)$, sodium bicarbonate, anti-inflammatory (benzydamine hydrochloride $0.15 \%$ ) and antimicrobial (chlorhexidine $0.12 \%$ ) as mouthwashes stand out symptoms of lowmoderate mucositis. For moderate symptoms, sialogogues, remineralizing agents (sodium fluoride $0.05 \%$ ), anesthetics (lidocaine $2.0 \%$ ) and other topical anti-inflammatory drugs such as steroids (triamcinolone acetonide $0.1 \%$ ) are used. Finally, for the most severe degree, opioids (morphine $0.2 \%$ ) are used topically or systemic. Thus, it is expected to achieve greater control of the mentioned signs and symptoms, contributing to an improvement in the patient's quality of life (Bensinger et al., 2008; Brown \& Gupta, 2020; Saunders et al., 2020; Miranda-Silva et al., 2020). 
Complications, initially non-infectious of $\mathrm{OM}$, may significantly compromise the chosen therapy, extend the hospitalization period and decrease the quality of life of patients with H\&N cancer (Elad et al., 2020). Its sequelae include dysphagia, dysgeusia, weight loss and secondary infections, which clinically manifest as stomatitis, usually caused by Candida albicans and the herpes simplex virus (Comodo et al., 2020).

Currently, the pathophysiology of OM comprised of five stages, namely: (i) Onset of damage to the oral mucosa; (ii) Primary damage due to the generation of reactive oxygen species; (iii) Expansion of lesions related to the patient's inflammatory response; (iv) Mucosal ulceration as a result of epithelial apoptosis and tissue necrosis - here, extremely painful lesions stand out, designated as passages for oral bacteria, causing infections; (v) Tissue repair due to suspension or termination of RT or CT treatment (Elad et al., 2020).

The repair or healing process involves several steps, but once complete, symptoms tend to disappear in the following days (Sonis, 2004). Even so, after the end of the healing process, the mucosa may persist with changes in its shape, due to changes in angiogenesis and fibroblasts (Almeida et al., 2009). For all these steps to be possible, cell multiplication and differentiation are necessary, until they become part of the mucosal tissue, without a limiting factor interfering with the repair in question. In the case of patients undergoing RT or CT, this process is complicated, and the role of substances capable of optimizing the stages of healing is therefore important. The ability of a substance to block or modify any of the steps in this process can result in successful prevention or management of mucositis (Sonis, 2004).

According to Verginadis et al. (2016), one of the common risks of RT is the development of lesions in the gastrointestinal mucosa, which lead to intestinal mucositis. In order to alleviate this situation and improve adherence to chemotherapy and radiotherapy treatment of patients, there are products on the market such as Ad-Muc ${ }^{\circledR}$ ointment, registered by the company Biolab Sanus Farmacêutica Ltd., located in Taboão da Serra, São Paulo, Brazil. This, in turn, is primarily indicated for the treatment of gingivitis, stomatitis and other inflammations of the oral cavity, being also indicated for episodes of oral irritation resulting from ill-fitting dentures (Anvisa, 2021a).

Among the constituents of this ointment, with anti-inflammatory property, is the extract of Chamomilla recutita (L) Rauschert $100 \mathrm{mg} / \mathrm{g}(10 \% \mathrm{~m} / \mathrm{m})$ as active pharmaceutical ingredient, in addition to glycerol, lanolin alcohols, cetostearyl alcohol, white petroleum jelly, solid petrolatum, xanthan gum, methylparaben, mint essence, myrrh tincture, mineral oil, sodium saccharin and purified water (Anvisa, 2021a). To chemical constituents such as camazulene, alpha-bisabolol, bisaboloxides and flavonoids, characteristic of extracts and essential oil of chamomile and that have anti-inflammatory, antibacterial, spastic, sedative and antifungal activities (Ribeiro et al., 2015; Buono-Core et al., 2011), is that the therapeutic potential of that ointment is attributed.

In this context, the therapeutic potential of chamomile extract is observed in relation to the management of oral sequelae resulting from the treatment of H\&N cancer. Therefore, the present work presents a narrative review that gathers, presents and discusses studies on the relationship between the topical application of chamomile-based pharmaceutical products and the treatment of oral mucositis, with an emphasis on its effectiveness.

\section{Methodology}

This is a narrative, qualitative review, with the following guiding question: What is the scientific evidence on the use of chamomile in the treatment of OM in patients undergoing chemotherapy and RT?

A literature search was conducted in August 2021 using PubMed, Scielo and LILACS. To search for articles, the following descriptors were used: "oral mucositis", "cancer" and "chamomille", using the Boolean operators "AND" and "OR". In the PubMed and Scielo databases, for the descriptor "chamomile", the Boolean operator "OR" was used, also including the keywords "matricaria" and "chamomilla", as an alternative for the searches of that descriptor. 
Original articles and case reports, published in English, Portuguese and Spanish, from 2005 to 2020, were included. Duplicate articles, comments, theses and dissertations, abstracts published in conference proceedings and scientific journals, letters to the editor, were excluded news, book chapters and review articles.

\section{Results}

From literature search was identified 869 papers, of which 06 were selected to answer the guiding question of this study. A flow diagram (Figure 1) was developed to demonstrate the steps in the process of this narrative review.

Figure 1. Steps taken in the selection of articles used in this narrative review.

\section{Articles found in databases}

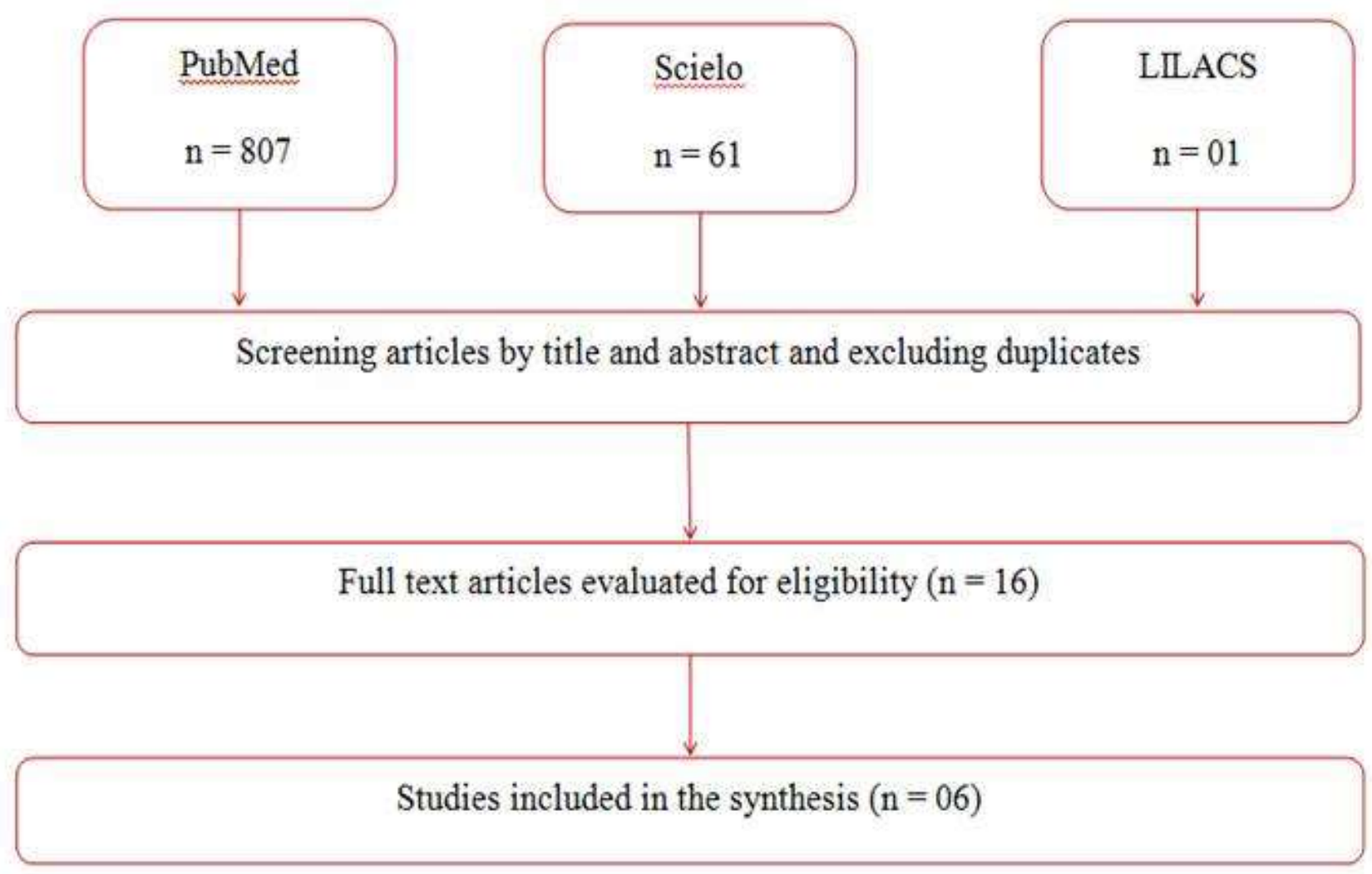

Source: Authors

Thus, carefully respecting the previously established inclusion and exclusion criteria, it was observed that, in general, the articles found present information on the use of chamomile in the treatment and prevention of OM, alleviating the symptoms and accelerating the healing process due to its anti-inflammatory properties (Table 1). 
Table 1. Characteristics of the included studies.

\begin{tabular}{|c|c|c|c|c|c|}
\hline $\begin{array}{l}\text { Author/ Year/ } \\
\text { Country }\end{array}$ & Objective & Study design & Results found & $\begin{array}{l}\text { Clinical } \\
\text { outcome }\end{array}$ & Limitations \\
\hline $\begin{array}{l}\text { Barreto et al./ } \\
\text { 2020/ Brazil }\end{array}$ & $\begin{array}{l}\text { Evaluate the influence of adopting oral hygiene } \\
\text { guidelines associated with the use of chamomile tea } \\
\text { in the prevention of OM in patients with solid } \\
\text { malignant tumors undergoing chemotherapy with } \\
\text { cytotoxic agents }\end{array}$ & $\begin{array}{l}\text { Pilot } \\
\text { randomized } \\
\text { clinical trial }\end{array}$ & $\begin{array}{l}\text { They did not find any significant difference between the } \\
\text { groups comparing the development of OM and the } \\
\text { reduction in salivary flow, evaluated for } 14 \text { days. } \\
\text { Afterwards, the development of OM was observed only in } \\
\text { the control group }(3 / 14=21.4 \% \text { ), which did not receive } \\
\text { guidance on oral hygiene and the use of chamomile }\end{array}$ & Yes & $\begin{array}{l}\text { Cytotoxic agents for the oral cavity } \\
\text { were selected for increasing the } \\
\text { predisposition to the development of } \\
\text { OM. However, the groups differed in } \\
\text { some types of chemotherapy, as well } \\
\text { as in the classification of tumors }\end{array}$ \\
\hline $\begin{array}{l}\text { Marucci et al./ } \\
\text { 2017/ Italy }\end{array}$ & $\begin{array}{l}\text { Evaluate the action, on acute mucositis, of a } \\
\text { mixture of natural agents, including } M \text {. } \\
\text { chamomilla, and compare with a placebo in patients } \\
\text { undergoing H\&N cancer }\end{array}$ & $\begin{array}{l}\text { Randomized } \\
\text { clinical trial }\end{array}$ & $\begin{array}{l}107 \text { patients were randomized from January } 2011 \text { to July } \\
2014 \text {, and } 104 \text { were evaluated ( } 51 \%-49 \% \text { were assigned } \\
\text { to the placebo group and } 53 \%-51 \% \text { were assigned to the } \\
\text { natural agent). Overall, } 61 \text { patients developed peak grade } 3 \\
\text { of OM with no difference }(\mathrm{p}=0.65)\end{array}$ & No & $\begin{array}{l}\text { The limited number of randomized } \\
\text { patients and the lack of correction for } \\
\text { the individual amount of mucosa } \\
\text { included in the RT fields weakened } \\
\text { the conclusions }\end{array}$ \\
\hline $\begin{array}{l}\text { Dos Reis et al./ } \\
\text { 2016/ USA- } \\
\text { Brazil }\end{array}$ & $\begin{array}{l}\text { Compare the effectiveness of conventional (water- } \\
\text { based) cryotherapy with a cryotherapy based on } \\
\text { chamomile infusion, in the prevention and } \\
\text { treatment of CT-induced OM }\end{array}$ & $\begin{array}{l}\text { Randomized } \\
\text { clinical trial }\end{array}$ & $\begin{array}{l}50 \% \text { of patients in the control group and } 30 \% \text { in the } \\
\text { chamomile group developed OM. Mouth pain scores were } \\
\text { significantly higher in control patients. Patients in the } \\
\text { chamomile group did not develop grade } 2 \text { of OM or higher }\end{array}$ & Yes & $\begin{array}{l}\text { Impossibility of using double } \\
\text { blinding, as it was not possible to } \\
\text { blind the patients regarding the flavor } \\
\text { and color of the ice chips (colorless } \\
\text { for the control and yellow for the } \\
\text { chamomile group) }\end{array}$ \\
\hline $\begin{array}{l}\text { Tavakoli et al./ } \\
\text { 2016/ } \\
\text { Iran }\end{array}$ & $\begin{array}{c}\text { Investigate the effects of Matricaria recutita and } \\
\text { Mentha piperita on OM in patients undergoing } \\
\text { HSCT }\end{array}$ & $\begin{array}{l}\text { Randomized } \\
\text { clinical trial }\end{array}$ & $\begin{array}{l}\text { The duration, maximum and mean daily degree of OM } \\
\text { were significantly reduced in the treatment group }(\mathrm{p}< \\
0.05) \text {. The use of herbal mouthwash led to significant } \\
\text { improvements in pain intensity }(\mathrm{p}=0.009) \text {, dryness }(\mathrm{p}= \\
0.04) \text { and dysphagia }(\mathrm{p}=0.009)\end{array}$ & Yes & - \\
\hline $\begin{array}{l}\text { Braga et al.I } \\
\quad \text { 2015/ } \\
\text { Brazil }\end{array}$ & $\begin{array}{l}\text { Identify the dosage of the hydroalcoholic extract of } \\
\text { chamomile in the mouthwash needed to reduce the } \\
\text { incidence and intensity of OM in adult patients } \\
\text { undergoing allogeneic HSCT }\end{array}$ & $\begin{array}{l}\text { Randomized } \\
\text { clinical trial }\end{array}$ & $\begin{array}{l}\text { The experimental group that received the dose reduced of } 1 \\
\% \text {, by three times, the incidence, intensity and duration of } \\
\text { OM compared to the control group. The formulation was } \\
\text { safe and well tolerated by patients, as no moderate or } \\
\text { severe adverse events were identified }\end{array}$ & Yes & $\begin{array}{l}\text { Impossibility of applying double } \\
\text { blinding, as it was not possible to } \\
\text { blind the patients regarding the color } \\
\text { of the mouthwash }\end{array}$ \\
\hline $\begin{array}{l}\text { Cardoso et al./ } \\
\text { 2005/ Brazil }\end{array}$ & $\begin{array}{l}\text { Assess the dental condition of patients with } \mathrm{H} \& \mathrm{~N} \\
\text { cancer undergoing surgery associated with RT or } \\
\text { exclusive RT, through a protocol able to visualize } \\
\text { possible changes in the different phases of } \\
\text { treatment, in order, through guidance and/or } \\
\text { treatment, to prevent, diagnose and control injuries } \\
\text { of the maxillomandibular complex resulting from } \\
\text { surgical and RT procedures }\end{array}$ & $\begin{array}{l}\text { Observational } \\
\text { prospective } \\
\text { cohort study }\end{array}$ & $\begin{array}{l}\text { The use of mouthwash with chamomile tea ( } 5 \mathrm{x} / \text { day) plays } \\
\text { an important role in the degree and relief of OM symptoms, } \\
\text { a fact associated with the anti-inflammatory action of } \\
\text { chamomile. The development of grade } 1 \text { OM may be } \\
\text { related to the application of preventive measures for oral } \\
\text { adequacy before the start of treatment, as well as the } \\
\text { maintenance of these measures during the period of RT }\end{array}$ & Yes & - \\
\hline
\end{tabular}

Legend: “-” = absence. Source: Authors. 


\section{Discussion}

$\mathrm{OM}$ is associated with a set of adverse events that can limit the patient's ability to tolerate anticancer treatment if not properly managed. Thus, it is crucial to develop effective preventive and curative treatment options in relation to this clinical condition. In this regard, it is worth commenting that in Brazil the importance of implementing natural products as a therapeutic alternative for various diseases has been seen since the publication of the National List of Medicinal Plants of Interest to the Unified Health System (RENISUS) (de Almeida et al., 2020).

According to Almeida et al. (2009), chamomile has therapeutic potential in relation to negative adverse events caused by RT and CT.

The papers selected in this study show, in their entirety, important data on the effects of substances extracted from chamomile and their participation in OM treatment protocols. In these, one can observe the scarcity of data and studies referring to adverse events related to the use of chamomile and other substances of natural origin in OM, especially in patients undergoing chemotherapy and RT.

Chamomile is one of several medicinal plants used in the treatment of pathologies of the oral cavity (Gomes et al., 2018). With approximately 120 bioactive substances, including 28 terpenoids, 36 flavonoids and 52 additional components, chamomile is responsible for several pharmacological activities (Buono-Core et al., 2011).

In addition, various types of treatments with other components and pharmaceutical forms are also reported, such as the plaster of flowering juices of Chamomilla recutita (L.) Rausch. [syn. Matricaria chamomilla L. and Matricaria recutita L.], which according to the Brazilian Pharmacopoeia (FB 6) must contain at least $0.4 \%$ volatile oil and at least $0.25 \%$ apigenin-7-O-glucoside $\left(\mathrm{C}_{21} \mathrm{H}_{20} \mathrm{O}_{10}, 432.38 \mathrm{~g} / \mathrm{mol}\right)$ (Agência Nacional de Vigilância Sanitária [ANVISA], 2019), which is rich in flavonoids, which allows for greater adherence to treatment, especially in terms of alleviating symptoms such as pain. The use of $10 \%$ aqueous extract, other fluid extracts and cryotherapy methods from chamomile infusion are also reported (BuonoCore et al., 2011; Mazokopakis et al., 2005).

Among the various botanical synonyms of chamomile that exist, the most used in studies for medicinal purposes is $M$. chamomilla, simply called chamomile, due to its widespread use in traditional medicine and its medicinal potential continuously described in the specialized literature, it has been the target of recurrent phytochemical investigations, which are important for the analysis of their pharmacological activities on the pathology highlighted in this review. Among these actives, we can highlight matricin and its transformation products (camazulene and alpha-bisabolol), whose biological activities are many, with emphasis on their anti-inflammatory and healing process stimulation properties (Anvisa, 2021a).

Among the pharmacological activities of camazulene, present in chamomile essential oil, its potential antiinflammatory action stands out, attributed to inhibition of leukotriene synthesis and additional antioxidant effects (Buono-Core et al., 2011). Spasmolytic, antipeptic and antibacterial effects described from the use of alpha-bisabolol are also reported (Mazokopakis et al., 2005).

A study that evaluated the daily use of chamomile tea as a mouthwash showed a reversal of grade 3 mucositis to grade 2 after 13 days of treatment, leading to complete healing in four weeks (Ribeiro et al., 2015). Of the selected articles, only one referred to adverse events, and the non-verification of their occurrence after the administration of mouthwashes containing chamomile extract was reported (Köstler et al., 2001).

According to Gomes et al. (2018), the anti-inflammatory activities of chamomile, especially the synonymy M. recutita, are mediated by the inhibition of prostaglandin release and induced by lipopolysaccharide and by the reduction of the activity of the type 2 cyclooxygenase enzyme (COX-2). Thus, it is noted that this medicinal plant has a high potential for the treatment of OM, as it can promote the inhibition of pro-inflammatory cytokine actions, influence the chemotaxis of leukocytes 
and lipopolysaccharides, in addition to promoting the activation of macrophages (Aghamohamamdi \& Hosseinimehr, 2015; Ribeiro et al., 2015).

The results presented by Barreto et al. (2020) demonstrate that chamomile tea associated with the provision of information related to correct techniques for oral hygiene, obtained non-significant results. However, in this study only patients undergoing chemotherapy were included. It is known that, according to Santos et al. (2011), the incidence of OM in patients undergoing cancer treatments is higher for those undergoing RT. This fact should be considered in the study by Barreto et al. (2020), for presenting a selection bias when defining the study inclusion criteria.

In the study by Marucci et al. (2016) a formulation was developed containing four agents that have anti-inflammatory action: propolis, aloe vera, calendula and chamomile. In this sense, through a randomized clinical study, the formulation did not show positive results for the prevention and treatment of OM. However, the presence of honey in the formulation may have masked the benefits of other anti-inflammatory agents, as it was present in both the control and intervention group formulations. It is known that this has reports of benefits for the prevention of OM.

In Brazil, a recent publication by the National Health Surveillance Agency [ANVISA] (2021b) cites four different extemporaneous preparations containing chamomile inflorescences, among which is the indication for use as an aid in the treatment of mild lesions and inflammation of the mouth and oropharynx for individuals above 12 years of age. Among the warnings is the contraindication for individuals with hypersensitivity to the components of the formulation and to species of the Asteraceae family, as well as hypersensitivity reactions of unknown frequency, including severe allergic reactions such as anaphylactic shock, vascular collapse, dyspnea and Quincke's disease, reported after mucosal contact with liquid preparations of . chamomilla. Furthermore, dermatological use is not recommended in case of deep or extensive lesions, as it can promote contact dermatitis and allergic reactions (Anvisa, 2021b).

Thus, when composing a pharmaceutical form, chamomile extract should be used respecting the usual concentrations that, according to Yarom et al. (2020), should be between 0.5 and $2.0 \%$ for topical use products such as mouthwashes. Added to this, the appropriate choice of other inactive pharmaceutical ingredients, which can impact the adherence to pharmacotherapy of the patient, whose oral mucosa is sensitive and inflamed (Ribeiro et al., 2020).

In fact, some substances can cause some discomfort while using the product. In this sense, Ribeiro et al. (2020) mentioned that multifunctional excipients such as sorbitol and glycerol, which have humectant and sweetening properties, however, are polyalcohols capable of interacting with water through hydrogen bonds and favoring tissue dryness. Other adjuvant substances such as azo dyes and sodium saccharin should be avoided as they promote adverse events.

In parallel, different potentially efficient excipients in the treatment of OM are indicated in the literature. Among these, the use of honey, zinc, selenium, topical vitamin E and glutamine stands out as complementary treatment to reduce the risk of developing OM during CT or RT (Gonçalves et al., 2020). It is also reported the use of sodium alginate with the potential to reduce the discomfort and severity resulting from the ulcerative process of this pathology, this by stimulating the synthesis of collagen and cell proliferation from the stimulus in the transformation of secretion of factor Beta 1 (TGF $\beta 1$ ) growth on skin wounds (Braga et al., 2015).

Despite the high therapeutic potential of chamomile, it is important to carefully choose the other pharmaceutical ingredients in the formulation, as well as the pharmaceutical form to be prepared to minimize discomfort during its use and ensure adherence to pharmacotherapy. It is noteworthy the lack of data on the use of sodium alginate and other substances that can help as a synergistic factor in formulations for topical use for the prevention and treatment of OM. In short, it is suggested that dosage forms containing chamomile be strategically optimized so that adjuvants do not interfere in the management of this pathology. 
In 2020, an impacting factor emerged in the treatment of patients with $\mathrm{H} \& \mathrm{~N}$ cancer due to the dissemination of the new coronavirus (Sars-Cov-2), responsible for Covid-19. This was due to the reduction in the number of surgeries performed due to the increase in medical demand aimed at controlling the pandemic and due to the increased incidence of this infection in health professionals. It was observed that, on average, $10 \%$ (from 4.8 to $37.5 \%$ ) of the H\&N cancer surgeons, who worked in reference oncology services, were contaminated with the virus. High contamination rates among health professionals reduced their availability for patient care (Gonçalves et al., 2020).

Furthermore, it is known that delays in diagnosis, surgeries, and treatments for H\&N cancer can significantly increase the attributable mortality rate when compared to the management of the Covid-19 pandemic. Both surgeries and treatments are highly impactful in terms of years of life gained by spent resources (Gonçalves et al., 2020).

\section{Final Considerations}

In view of the bibliographical survey carried out, it could be seen that chamomile has a great potential to help manage OM, as well as other oral complications, especially in cases of patients undergoing H\&N cancer treatments using RT. Furthermore, formulations containing chamomile have been shown to be effective in slowing the progression of OM grades. However, it is necessary to evaluate in each formulation, the possible impacts of each pharmaceutical adjuvant, as well as the adverse events that increase the pharmacotherapeutic adherence.

To definitively clarify the effectiveness of chamomile in the treatment of OM, it is suggested to carry out a randomized clinical study in patients undergoing HSCT, RT or RT associated with CT, using different formulations containing exclusively chamomile and appropriate adjuvants.

\section{Acknowledgments}

To the Dean of Research and Graduate Studies (PROPE) at the Federal University of São João del-Rei (UFSJ) for granting financial assistance, through the Institutional Program for Scientific Initiation Scholarships, modality PIDACAf/UFSJ.

\section{Conflict of Interest}

The authors report that they do not have any conflicts of interest.

\section{Contribution of the Authors}

H. T. C. Santos developed the present work as a scholarship holder of the Institutional Program for Academic Development in Affirmative Actions of the Federal University of São João del-Rei (PIDAC-Af/UFSJ). The other authors aided in the selection of articles used in this review, in addition to interpreting and discussing the results found. M. C. Coimbra was responsible for the co-orientation of this work. A. E. Meri Jun was also responsible for providing rigorous methodological support. A. J. P. S. Gomes was responsible for the orientation of this work and improved the manuscript.

\section{References}

Agência Nacional de Vigilância Sanitária (2021a). Ad-Muc ${ }^{\circledR}$. https://consultas.anvisa.gov.br/\#/bulario/q/?nomeProduto=AD-MUC

Agência Nacional de Vigilância Sanitária (2019). Farmacopeia Brasileira. Volume II - Monografias Plantas Medicinais. (6a ed.). https://www.gov.br/anvisa/pt-br/assuntos/farmacopeia/farmacopeia-brasileira/arquivos/7989json-file-1

Agência Nacional de Vigilância Sanitária (2021b). Formulário de Fitoterápicos da Farmacopeia Brasileira. (2a ed.). https://www.gov.br/anvisa/ptbr/assuntos/farmacopeia/formulario-fitoterapico/arquivos/2021-fffb2-final-c-capa2.pdf 
Aghamohamamdi, A., \& Hosseinimehr, S. J. (2016). Natural Products for Management of Oral Mucositis Induced by Radiotherapy and Chemotherapy. Integrative Cancer Therapies, 15(1), 60-68. https://doi.org/10.1177/1534735415596570

Almeida, P. N. M., Albuquerque, R. A., Roesler, E., \& Sobral, A. P. V. (2009). Radioinduced oral mucositis in patients with head and neck malignant neoplasms: Epidemiological study. Revista de Odontologia da UNESP, 4(38), 211-216.

Barreto, A. B. R., Dantas, B. L. J., Martins, B. G., Sanches, B. A. C., Carrera, M., Reis, A. S. R., \& Medrado, R. A. P. A. (2020). Avaliação do Impacto da Higiene Oral Associada ao Uso do Chá de Camomila no Desenvolvimento de Mucosite Oral: Estudo-Piloto. Revista Brasileira de Cancerologia, 66(1), e10777. https://doi.org/10.32635/2176-9745.RBC.2020v66n1.777

Bensinger, W., Schubert, M., Ang, K. K., Brizel, D., Brown, E., Eilers, J. G., Elting, L., Mittal, B. B., Schattner, M. A., Spielberger, R., Treister, N. S., \& Trotti, A. M., 3rd (2008). NCCN Task Force Report. Prevention and management of mucositis in cancer care. Journal of the National Comprehensive Cancer Network: JNCCN, 6 Suppl 1, S1-S24

Braga, F. T., Santos, A. C., Bueno, P. C., Silveira, R. C., Santos, C. B., Bastos, J. K., \& Carvalho, E. C. (2015). Use of Chamomilla recutita in the Prevention and Treatment of Oral Mucositis in Patients Undergoing Hematopoietic Stem Cell Transplantation: A Randomized, Controlled, Phase II Clinical Trial. Cancer Nursing, 38(4), 322-329. https://doi.org/10.1097/NCC.0000000000000194

Brown, T. J., \& Gupta, A. (2020). Management of Cancer Therapy-Associated Oral Mucositis. JCO Oncology Practice, 16(3), 103-109. https://doi.org/10.1200/JOP.19.00652

Buono-Core, G. E., Nuñez, M. V., Lucero, A., Vargas M, R., \& Jullian, C. (2011). Structural elucidation of bioactive principles in floral extracts of german chamomille (Matricaria Recutita L.). Journal of the Chilean Chemical Society, 56(1), 549-553. http://dx.doi.org/10.4067/S0717-97072011000100006

Cardoso, M. d. F. A., Novikoff, S., Tresso, A., Segreto, R. A., \& Cervantes, O. (2005). Prevenção e controle das seqüelas bucais em pacientes irradiados por tumores de cabeça e pescoço. Radiologia Brasileira, 38(2), 107-115.

Comodo, G. V., Palma, L. F., Dos Santos, M. S., Seoanes, G. A., Gonnelli, F. A. S., Segreto, R. A., Segreto, H. R. C., \& Reimão, J. Q. (2020). Infecções orais oportunistas em pacientes submetidos à radioterapia para câncer de cabeça e pescoço: um estudo retrospectivo. Research, Society and Development, 9(3), Artigo e164932685. http://dx.doi.org/10.33448/rsd-v9i3.2685

Daugèlaitė, G., Užkuraitytė, K., Jagelavičienè, E., \& Filipauskas, A. (2019). Prevention and Treatment of Chemotherapy and Radiotherapy Induced Oral Mucositis. Medicina (Kaunas, Lithuania), 55(2), 25. https://doi.org/10.3390/medicina550200255

de Almeida, E. M., Ferreira, H. J., Alves, D. R., \& da Silva, W. (2020). Therapeutic potential of medicinal plants indicated by the Brazilian public health system in treating the collateral effects induced by chemotherapy, radiotherapy, and chemoradiotherapy: A systematic review. Complementary Therapies in Medicine, 49, 102293. https://doi.org/10.1016/j.ctim.2019.102293

Medeiros, N. J., Medeiros, N. F., Santos, C. C., Parente, G. V., \& Carvalho, J. N. (2013). Low-power laser therapy in chemical-induced oral mucositis: a case study. Brazilian Journal of Otorhinolaryngology, 79(6), 792. https://doi.org/10.5935/1808-8694.20130143

Dos Reis, P. E., Ciol, M. A., de Melo, N. S., Figueiredo, P. T., Leite, A. F., \& Manzi, N. (2016). Chamomile infusion cryotherapy to prevent oral mucositis induced by chemotherapy: a pilot study. Supportive Care in Cancer: Official Journal of the Multinational Association of Supportive Care in Cancer, 24(10), 4393-4398. https://doi.org/10.1007/s00520-016-3279-y

Elad, S., Cheng, K., Lalla, R. V., Yarom, N., Hong, C., Logan, R. M., Bowen, J., Gibson, R., Saunders, D. P., Zadik, Y., Ariyawardana, A., Correa, M. E., Ranna, V., Bossi, P., \& Mucositis Guidelines Leadership Group of the Multinational Association of Supportive Care in Cancer and International Society of Oral Oncology (MASCC/ISOO) (2020). MASCC/ISOO clinical practice guidelines for the management of mucositis secondary to cancer therapy. Cancer, 126(19), 4423-4431. https://doi.org/10.1002/cncr.33100

Gomes, V., Nonato Silva Gomes, R., Gomes, M. S., Joaquim, W. M., Lago, E. C., \& Nicolau, R. A. (2018). Effects of Matricaria Recutita (L.) in the Treatment of Oral Mucositis. TheScientificWorldJournal, 2018, 4392184. https://doi.org/10.1155/2018/4392184

Gonçalves, S., Kulcsar, M. A. V., Matos, L. L., Vartanian, J. G., Carvalho, G. B., Dias, F. L., Farias, T. P., Tosto, E., Santos, C. R., Silva, L. G., Javaroni, A. C., Ramos, G. H. A., Cavalheiro, B. G., Oliveira, J. C., Cicco, R., Mello, L. E. B., Melo, B. C., Santos, L. R. M., Goulart, R. N., \& Kowalski, L. P. (2020). Overview of care for head and neck cancer cases in Brazilian Cancer Centers during the COVID-19 pandemic. Archives of Head and Neck Surgery, 49. http://dx.doi.org/10.4322/ahns.2020.0008

Hong, C., Gueiros, L. A., Fulton, J. S., Cheng, K., Kandwal, A., Galiti, D., Fall-Dickson, J. M., Johansen, J., Ameringer, S., Kataoka, T., Weikel, D., Eilers, J., Ranna, V., Vaddi, A., Lalla, R. V., Bossi, P., Elad, S., \& Mucositis Study Group of the Multinational Association of Supportive Care in Cancer/International Society for Oral Oncology (MASCC/ISOO) (2019). Systematic review of basic oral care for the management of oral mucositis in cancer patients and clinical practice guidelines. Supportive Care in Cancer: Official Journal of the Multinational Association of Supportive Care in Cancer, 27(10), 3949-3967. https://doi.org/10.1007/s00520-019-04848-4

Kawashita, Y., Soutome, S., Umeda, M., \& Saito, T. (2020). Oral management strategies for radiotherapy of head and neck cancer. The Japanese Dental Science Review, 56(1), 62-67. https://doi.org/10.1016/j.jdsr.2020.02.001

Köstler, W. J., Hejna, M., Wenzel, C., \& Zielinski, C. C. (2001). Oral mucositis complicating chemotherapy and/or radiotherapy: options for prevention and treatment. CA: A Cancer Journal for Clinicians, 51(5), 290-315. https://doi.org/10.3322/canjclin.51.5.290

Marucci, L., Farneti, A., Di Ridolfi, P., Pinnaro, P., Pellini, R., Giannarelli, D., Vici, P., Conte, M., Landoni, V., \& Sanguineti, G. (2017). Double-blind randomized phase III study comparing a mixture of natural agents versus placebo in the prevention of acute mucositis during chemoradiotherapy for head and neck cancer. Head \& Neck, 39(9), 1761-1769. https://doi.org/10.1002/hed.24832

Mazokopakis, E. E., Vrentzos, G. E., Papadakis, J. A., Babalis, D. E., \& Ganotakis, E. S. (2005). Wild chamomile (Matricaria recutita L.) mouthwashes in 
Research, Society and Development, v. 10, n. 14, e433101422081, 2021

(CC BY 4.0) | ISSN 2525-3409 | DOI: http://dx.doi.org/10.33448/rsd-v10i14.22081

methotrexate-induced oral mucositis. Phytomedicine: International Journal of Phytotherapy and Phytopharmacology, 12(1-2), 25-27. https://doi.org/10.1016/j.phymed.2003.11.003

Miranda-Silva, W., Gomes-Silva, W., Zadik, Y., Yarom, N., Al-Azri, A. R., Hong, C., Ariyawardana, A., Saunders, D. P., Correa, M. E., Arany, P. R., Bowen, J., Cheng, K., Tissing, W., Bossi, P., Elad, S., \& Mucositis Study Group of the Multinational Association of Supportive Care in Cancer / International Society for Oral Oncology (MASCC/ISOO) (2021). MASCC/ISOO clinical practice guidelines for the management of mucositis: sub-analysis of current interventions for the management of oral mucositis in pediatric cancer patients. Supportive Care in Cancer: Official Journal of the Multinational Association of Supportive Care in Cancer, 29(7), 3539-3562. https://doi.org/10.1007/s00520-020-05803-4

Ribeiro, A. C. L., Silva, M. G., Tavares, H. S., Solano, A. G. R, \& Gomes, A. J. P. S. (2020). Study of a tooth gel formulation for hygiene and oral sequelae management in irradiated patients. Journal of Applied Pharmaceutical Science, 10(6), 116-122. https://doi.org/10.7324/JAPS.2020.10615

Ribeiro, I. L. A., Medeiros, J. J. d., Rodrigues, L. V., Valença, A. M. G., \& Lima Neto, E. d. A. (2015). Factors associated with lip and oral cavity cancer. Revista Brasileira de Epidemiologia, 18(3), 618-629. https://doi.org/10.1590/1980-5497201500030008

Santos, R. C. S., Dias, R. S., Giordani, A. J., Segreto, R. A., \& Segreto, H. R. C. (2011). Mucosite em pacientes portadores de câncer de cabeça e pescoço submetidos à radioquimioterapia. Revista da Escola de Enfermagem da USP, 45(6), 1338-1344. https://doi.org/10.1590/S0080-62342011000600009

Sari, J., Nasiloski, K. S., \& Gomes, A. P. N. (2014). Oral complications in patients receiving head and neck radiation therapy: a literature review. Revista Gaúcha de Odontologia, 62(4), 395-400. https://doi.org/10.1590/1981-863720140004000007573

Saunders, D. P., Rouleau, T., Cheng, K., Yarom, N., Kandwal, A., Joy, J., Bektas Kayhan, K., van de Wetering, M., Brito-Dellan, N., Kataoka, T., Chiang, K., Ranna, V., Vaddi, A., Epstein, J., Lalla, R. V., Bossi, P., Elad, S., \& Mucositis Study Group of the Multinational Association of Supportive Care in Cancer/International Society of Oral Oncology (MASCC/ISOO) (2020). Systematic review of antimicrobials, mucosal coating agents, anesthetics, and analgesics for the management of oral mucositis in cancer patients and clinical practice guidelines. Supportive Care in Cancer: Official Journal of the Multinational Association of Supportive Care in Cancer, 28(5), 2473-2484. https://doi.org/10.1007/s00520-019-05181-6

Sonis S. T. (2004). Pathobiology of mucositis. Seminars in oncology nursing, 20(1), 11-15. https://doi.org/10.1053/j.soncn.2003.10.003

Tavakoli Ardakani, M., Ghassemi, S., Mehdizadeh, M., Mojab, F., Salamzadeh, J., Ghassemi, S., \& Hajifathali, A. (2016). Evaluating the effect of Matricaria recutita and Mentha piperita herbal mouthwash on management of oral mucositis in patients undergoing hematopoietic stem cell transplantation: A randomized, double blind, placebo controlled clinical trial. Complementary Therapies in Medicine, 29, 29-34. https://doi.org/10.1016/j.ctim.2016.08.001

Verginadis, I. I., Kanade, R., Bell, B., Koduri, S., Ben-Josef, E., \& Koumenis, C. (2017). A Novel Mouse Model to Study Image-Guided, Radiation-Induced Intestinal Injury and Preclinical Screening of Radioprotectors. Cancer Research, 77(4), 908-917. https://doi.org/10.1158/0008-5472.CAN-16-2724

Yarom, N., Hovan, A., Bossi, P., Ariyawardana, A., Jensen, S. B., Gobbo, M., Saca-Hazboun, H., Kandwal, A., Majorana, A., Ottaviani, G., Pentenero, M., Nasr, N. M., Rouleau, T., Lucas, A. S., Treister, N. S., Zur, E., Ranna, V., Vaddi, A., Barasch, A., Lalla, R. V., ... Mucositis Study Group of the Multinational Association of Supportive Care in Cancer / International Society of Oral Oncology (MASCC/ISOO) (2020). Systematic review of natural and miscellaneous agents, for the management of oral mucositis in cancer patients and clinical practice guidelines - part 2: honey, herbal compounds, saliva stimulants, probiotics, and miscellaneous agents. Supportive Care in Cancer: Official Journal of the Multinational Association of Supportive Care in Cancer, 28(5), 2457-2472. https://doi.org/10.1007/s00520-019-05256-4 